\title{
KÖK HÜCRE
}

\author{
Biyolojisi, Türleri ve \\ Tedavide Kullanımları
}





\title{
KÖK HÜCRE
}

\section{Biyolojisi, Türleri ve Tedavide Kullanımları}

\author{
İkinci Bask1
}

\section{Prof. Dr. Alp Can}

Ankara Üniversitesi Tıp Fakültesi

Histoloji ve Embriyoloji Anabilim Dalı

Üreme Biyolojisi ve Kök Hücre Laboratuvarları

www.alpcan.com

2021, Ankara 


\title{
(C) Copyright 2021
}

Bu kitabın, basım, yayın ve satış hakları Akademisyen Kitabevi A.Ş.'ne aittir. Anılan kuruluşun izni alınmadan kitabın tümü ya da bölümleri mekanik, elektronik, fotokopi, manyetik kağıt ve/veya başka yöntemlerle çoğaltılamaz, basılamaz, dağıtılamaz. Tablo, şekil ve grafikler izin alınmadan, ticari amaçh kullanılamaz. Bu kitap T.C. Kültür Bakanlı̆̆ bandrolü ile satılmaktadır.

$\begin{aligned} \text { ISBN } & \text { Kapak Mikrografı } \\ \text { 978-625-7409-62-9 } & \text { Çizgili iskelet kası gelişiminde yer alan } \\ & \text { fibroblastlar, uydu hücreler (çekirdekleri kırmızı) } \\ \text { Kitap Adı } & \text { ve aktin miyofilamanları (yüksek çözünürlük } \\ \text { Kök Hücre } & \text { konfokal mikroskopi) }\end{aligned}$

Biyolojisi, Türleri ve Tedavide Kullanımları

Yayıncı Sertifika No

Yazar

47518

Prof. Dr. Alp CAN

ORCID iD: 0000-0002-5393-6115

Baskı ve Cilt

Özyurt Matbaacılık

\author{
Yayın Koordinatörü \\ Yasin DİLMEN \\ Bisac Code \\ SCI017000 \\ $\begin{aligned} \text { Mizanpaj } & \text { DOI } \\ \text { Dilek MERAKİ } & 10.37609 / \text { akya.259 }\end{aligned}$
}

Kapak Mikrografı ve Kitabın Tasarımı

Prof. Dr. Alp CAN

\section{UYARI}

Bu üründe yer alan bilgiler sadece lisanslı tıbbi çalışanlar için kaynak olarak sunulmuştur. Herhangi bir konuda profesyonel tıbbi danışmanlık veya tıbbi tanı amacıyla kullanılmamalıdır. Akademisyen Kitabevi ve alıcı arasında herhangi bir şekilde doktor-hasta, terapist-hasta ve/veya başka bir sağlık sunum hizmeti ilişkisi oluşturmaz. $\mathrm{Bu}$ ürün profesyonel tıbbi kararların eşleniği veya yedeği değildir. Akademisyen Kitabevi ve bağlı şirketleri, yazarları, katılımcıları, partnerleri ve sponsorları ürün bilgilerine dayalı olarak yapılan bütün uygulamalardan doğan, insanlarda ve cihazlarda yaralanma ve/veya hasarlardan sorumlu değildir.

İlaçların veya başka kimyasalların reçete edildiği durumlarda, tavsiye edilen dozunu, ilacın uygulanacak süresi, yöntemi ve kontraendikasyonlarını belirlemek için, okuyucuya üretici tarafından her ilaca dair sunulan güncel ürün bilgisini kontrol etmesi tavsiye edilmektedir. Dozun ve hasta için en uygun tedavinin belirlenmesi, tedavi eden hekimin hastaya dair bilgi ve tecrübelerine dayanak oluşturması, hekimin kendi sorumluluğundadır.

Akademisyen Kitabevi, üçüncü bir taraf tarafından yapılan ürüne dair değişiklikler, tekrar paketlemeler ve özelleştirmelerden sorumlu değildir.

\section{GENEL DAĞITIM}

\section{Akademisyen Kitabevi A.Ş.}

Halk Sokak 5 / A

Yenişehir / Ankara

Tel: o312 4311633

siparis@akademisyen.com 


\section{İÇİNDEKİLER}

Önsöz (Birnci Bask1) ........................................................ 1

Önsöz (İkinci Baskı) .................................................... 3

Teşekkür ............................................................................. 4

Kitapta Kullanılan Yabancı Terimler,

Kısaltmalar ve Türkçe Karşılıkları.....

KISIM I

KÖK HÜCRE BIYYOLOJİSi

\author{
1. BÖL ÜM \\ GİRIŞ VE TANIMLAR
}

Kök Hücrenin Tanımı. .41

\section{BÖL ÜM HÜCRELERDE GELİŞIM HİYERARŞİS İ}

Zigot ve Öncesi. 50

Blastokiste Giden Süreç .53

Birinci Hücre Kararlanması 55

İkinci Hücre Kararlanması . .56

Hipoblastın (İlkel Endoderm) İleri Gelişmesi............ 60

Trofoektodermin İleri Gelişmesi.................................. 61

Epiblastın (İlkel Ektoderm) İleri Gelişmesi ................ 64

Gastrülasyonu ve İleri Farklılaşmasını

Düzenleyen Faktörler 67

Ektodermin İleri Gelişmesi 71

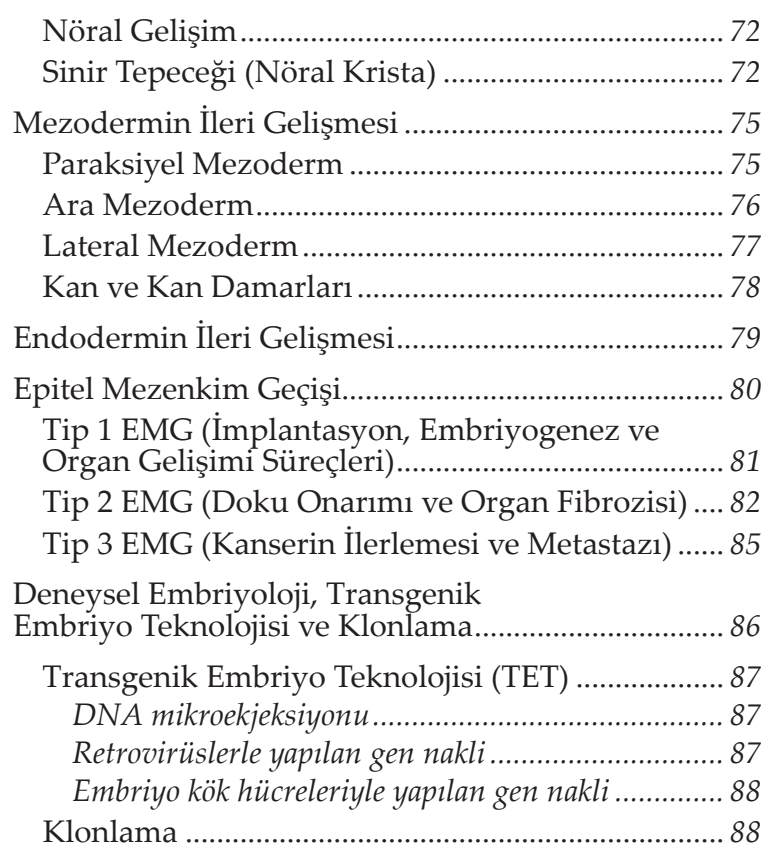

\section{BÖLÜM MOLEKÜLER HÜCRE BIYYOLOJISIINE KISA B AKIŞ}

Genler ve Genom Yapisı............................................... 98

Kromozomlar, Kromatin ve Histonlar...................... 100

Sentromerler.............................................................. 104

Telomerler............................................................... 104

X-kromozumunun Etkinsizleşmesi ........................... 106

Genom Damgalanması (Imprinting)....................... 108

RNA Sentezi (DNA'nın transkripsiyonu) ................. 109

Başlama öncesi (pre-initiation) .............................. 109

Başlama ........................................................... 110

Promotörün ayrılmast ......................................... 110 


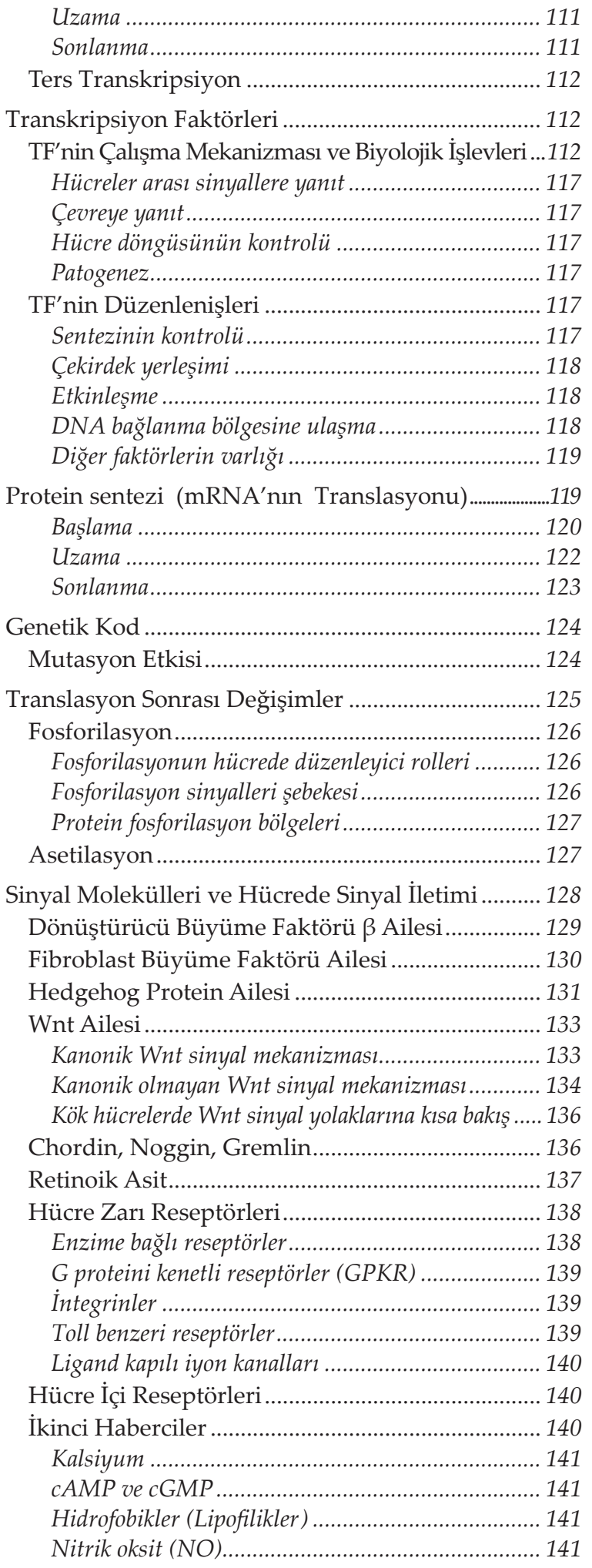

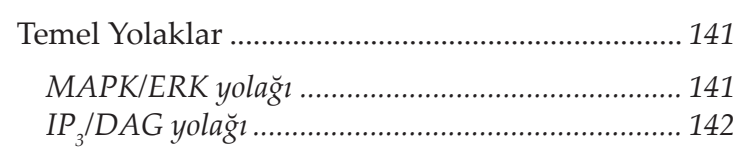

\section{B ÖL ÜM KÖK HÜCRELERİN TEMEL ÖZELLİKLERİ}

\section{BÖL ÜM KÖK HÜCRE Níşi}

Giriş ve Tanım.............................................................. 175

Kıl Folikülü ve Kök Hücre Nişi................................... 180

Bağırsak Mukozası Nişi .................................................. 185

Kıl Folikülü Nişi ile Bağırsak Nişinin

Karşılaştırılması......................................................... 187

Hematopoetik Kök Hücre Nişi ................................... 188

Hematopoetik Nişin Hücresel Bileşenleri .............. 191

Hematopoetik Nişin Hücre Dışı Bileşenleri .......... 195

Tedavi Amacıyla HKH Nişinin Hedeflenmesi..... 196 


\section{BÖLÜM KÖK HÜCRELERİN YASAM DÖNGÜSÜ, STRES VE YAŞLANMA}

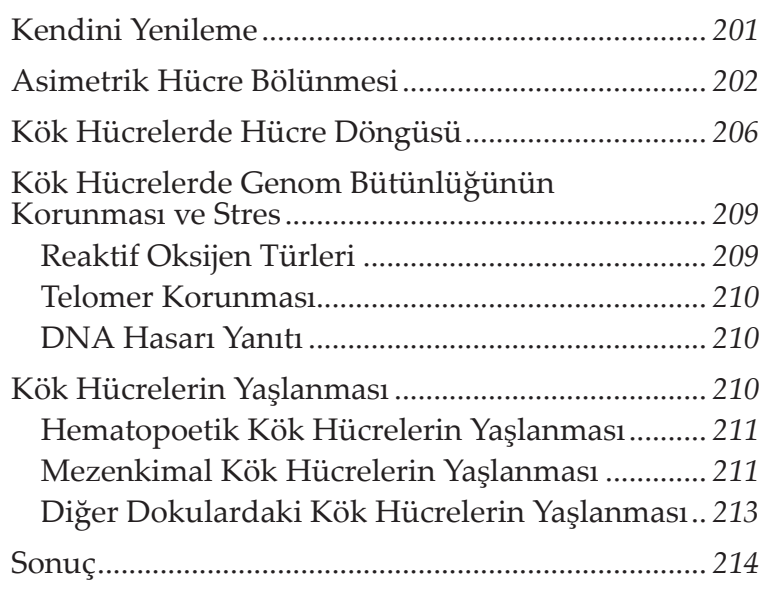

\section{KISIM II \\ KÖK HÜCRE TÜRLERİ}

\section{BÖLÜM \\ PLURIPOTENTKÖKHÜCRELER}

Embriyo Kök Hücreleri ..................................................... 223

Farede Embriyo Kök Hücreleri ................................. 224

İnsanda Embriyo Kök Hücreleri ................................ 226

Embriyonumsu Cisimler ........................................... 228

İnsanda EKH'nin Elde Edilmesi............................... 231

Klinik Kalitede İnsan Embriyosu Kök Hücreleri.. 234

Embriyo Kök Hücrelerinin in vitro

Farklılaşma Yetkinlikleri ............................................ 235

Ektoderm yönünde farklılaşma................................. 237

Mezoderm yönünde farklılaşma ............................... 239

Endoderm yönünde farklılaşma................................ 240

Germ hücresi yönünde farklılaşma .......................... 241

İnsan Embriyosu Kök Hücrelerinin Saklanması . 242

Diğer Pluripotent Kök Hücreler................................... 243

Epiblast Kök Hücreleri (EpiKH) ................................ 243

Embriyo Karsinoma Hücreleri (EKaH) ................... 244

Embriyo Germ Hücreleri (EGH) .............................. 245
Embriyo Kök Hücresi Benzeri Çok Küçük

(VSEL) Hücreler............................................................ 246

İlkel Cinsiyet (Primordiyal Germ) Hücreleri ............ 248

İlkel Cinsiyet Hücrelerinin Türevleri ...................... 251

\section{B ÖL ÜM \\ UYARILMIŞ PLURIPOTENT KÖK HÜCRELER}

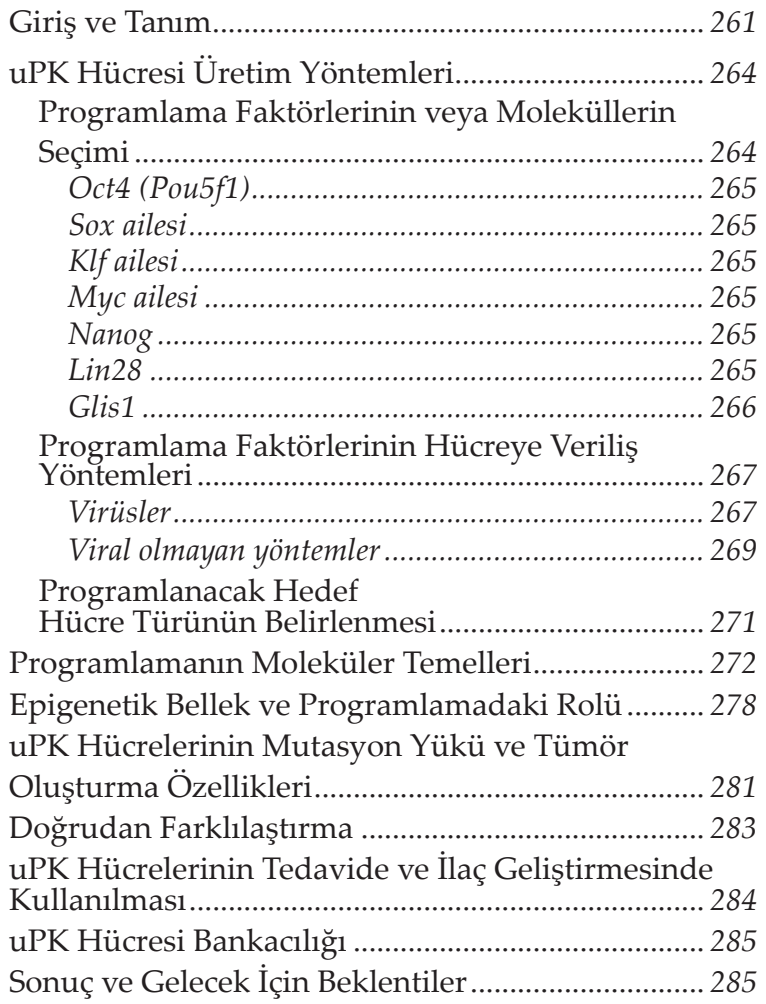

\section{BÖL ÜM}

EMBRIYYVEFETÜSKAYNAKLI MULTİPOTENTKÖKHÜCRELER

Trofoblast Kök Hücreleri

Sinir Tepeciği (Nöral Krista) Kaynaklı Kök Hücreler . 295

Nöral Krista Hücrelerinin Alternatif Kaynakları.. 298

Göç Sonrasındaki Nöral Krista Kök Hücreleri .... 298

Siyatik sinir ve bağırsak sinir sistemi 299 
Arka kök gangliyonu (AKG) ............................... 299

Kemik iliği .................................................... 300

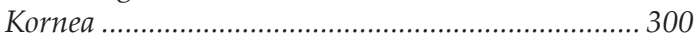

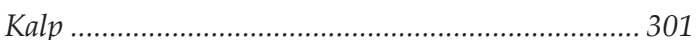

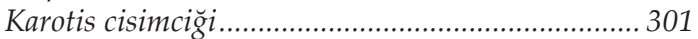

Diş pulpast ve periyodontal ligament ..................... 301

Derideki nöral krista kök hücreleri........................... 302

Yüz derisindeki nöral krista kök hücrelerinin kökeni......302

Gövde derisindeki nöral krista kök hücreleri ve

diğer multipotent kök hücreler ....................................303

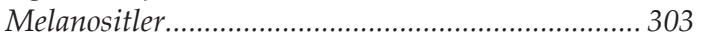

Amniyon ve Plasenta Kaynaklı Kök Hücreler......... 304

Amniyon Zarı Epiteli Hücreleri .............................. 306

Amniyon Zarı ve Koryon Plakasındaki

Mezenkim/Stroma Kök Hücreleri.......................... 307

Amniyon Sıvısındaki Kök Hücreler ...................... 309

Göbek Kordonu Kaynaklı Kök Hücreler........................ 311

Stroma Hücrelerinin Kök Hücre Özellikleri ........ 312

Göbek Kordonundaki Diğer Kök Hücreler .......... 319

\section{BÖLÜM YETISŞKIN KÖK HÜCRELER}

Yetişkin Kök Hücreler.

KISIM III

KÖK HÜCRELERİN YETISSTIN VÜCUDUNDAKİ DAĞILIMI VE TEDAVIIDEKİ YERLERI

\section{B ÖL ÜM \\ KEMİKİLIĞİVEKORDONKANI KÖK HÜCRELERI}

Prenatal Dönemde Hematopoez

Yetişkinde Hematopoez ve Hematopoetik Kök

Hücreler

Hematopoetik Kök Hücre Türleri.

339

Hematopoetik Kök Hücre Belirteçleri....

341
Hematopoetik Kök Hücre ile Nişi Arasındaki

İlişkiler 343

Hematopoetik Kök Hücrelerin Çoğalma

Dinamikleri 345

Hematopoetik Kök Hücrelerin Mobilizasyonu ve

Yerleşimi

Kordon Kanındaki Kök Hücreler ............................ 347

Kordon Kanındaki Hematopoetik Kök Hücreler ..347

Kordon Kanındaki Mezenkimal Kök Hücreler.... 348

Kordon Kanındaki Multipotent Kök Hücreler .... 349

Kordon Kanı Kökenli Hücrelerin Klinik Önemi.. 350

Kordon kanı kaynaklı multipotent kök hücrelerin

deneysel ve klinik olgularda kullanımı....

Kordon Kanı Hücrelerinin Geleceği ...................... 352

Kordon Kanı Bankacılı̆ğ ........................................ 353

\section{B ÖL ÜM \\ MEZENKIMALKÖKHÜCRELER}

Giriş ve Tanım................................................................... 363

MKH'nin Vücut İçindeki Karşılıkları........................ 366

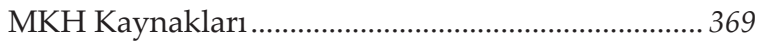

Kemik İliği ve Kan Kaynaklı Mezenkimal Kök

Hücreler ..................................................................... 370

Kİ-MKH'nin klinik amaçla ayrıştırılması,

kültürü̈ ve dondurulmast ....................................... 374

Kordon Kanı Kaynaklı Mezenkimal Kök Hücreler. 374

Yağ Dokusu Kaynaklı Mezenkimal Kök Hücreler..375

MKH'nin İmmünfenotiplendirilmesi......................... 377

Temel Doku Uyumluluğu

Kompleksi (MHC) Sinıf I ve Sinif II...................... 377

İşlev Analizleri: MKH'nin in vitro Farklılaştırılması .. 379

Kültür Ortamı ve Serumun Önemi......................... 380

Osteojenik Farklılaşma .............................................. 380

Kondrojenik Farklılaşma.......................................... 383

Adipojenik Farklılaşma ............................................ 385

Endotel Hücresine Farklılaşma ............................... 389

Düz Kas Hücresine Farklılaşma.............................. 392

Kardiyomiyosite Farklılaşma .................................... 393

MKH'nin Diğer Hücre Türlerine

in vitro Farklilaşması .............................................. 393

Nörojenik farklılaşma ............................................ 394

Hepatojenik farklılaşma ....................................... 396

Cevre Faktörlerinin ve mikro RNA'ların MKH'nin Ủzerine Etkisi............................................................ 397

MKH'nin Yaşlanması ve Neoplaziye Dönüşümü ... 398

MKH'nin Parakrin Etkileri ve 
Doku Onarımındaki Rolleri........................................ 398

MKH'nin Dokuya Yerleşmesi................................ 401

MKH'nin İmmün Sistemi Düzenleyici Etkileri ....... 403

MKH'nin Tedavide ve Onarım Tibbında Kullanımı...404

GVHH'de MKH Uygulaması. .409

Sonuç 410

\section{BÖLÜM}

KASVEISKELETSISTEMINDEKI KÖK HÜCRELER

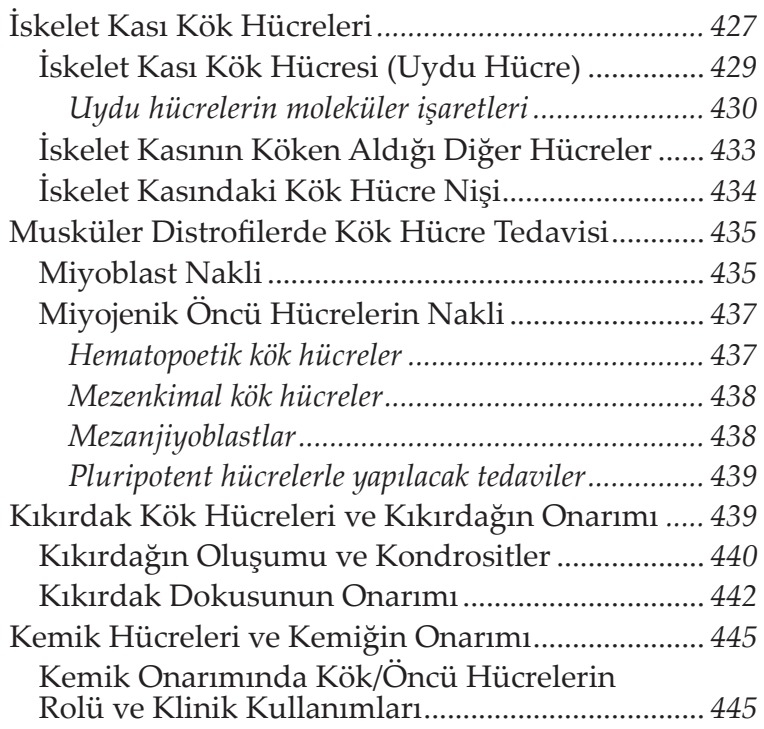

\section{BÖL ÜM KALPVEDAMARSİSTEMINDEKİ KÖK HÜCRELER}

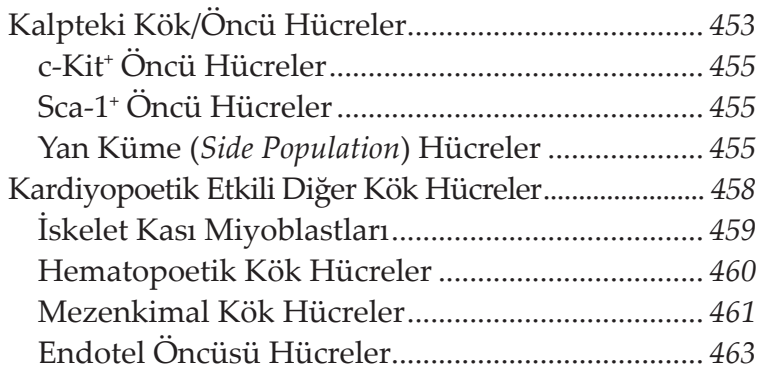

Uyarılmış Pluripotent Kök Hücreler ...................... 464

Kök Hücrelerin Kalpteki Etki Mekanizmaları ..... 464

Kalp Hastalıklarının Hücre İle Tedavisi ........................ 465

Endotel Öncüsü Hücreler ........................................... 467

Endotel Öncüsü Hücrelerin Tanımlanması .......... 468

Tromboanjitis Obliterans'ın Tedavisinde

Kök Hücrelerin Kullanımı 470

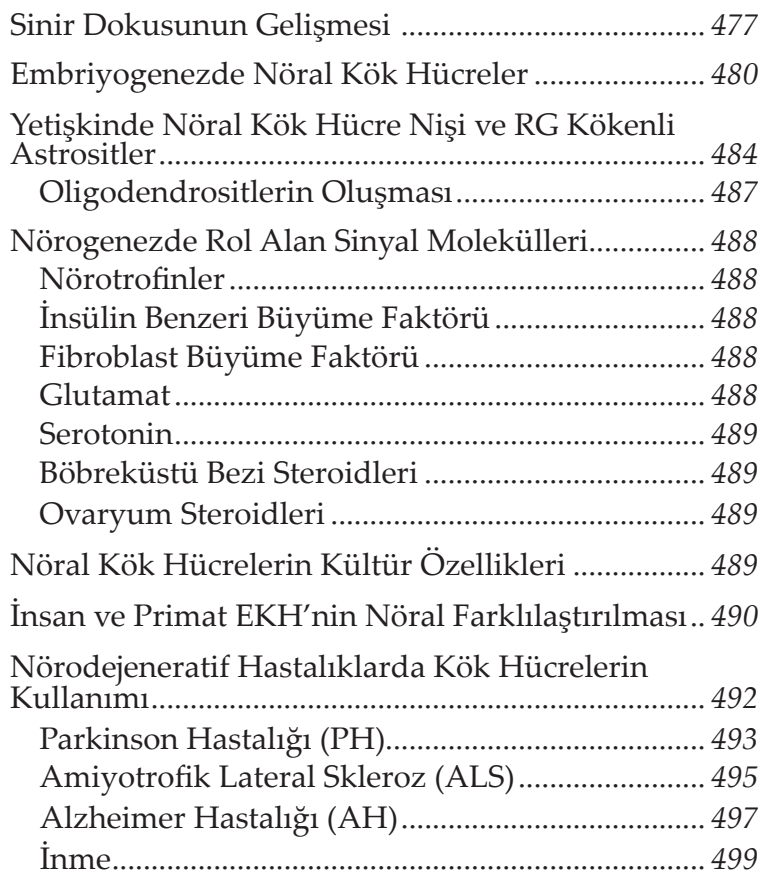

Omurilik Yararlanmalarında Kök Hücre Tedavisinin

Yeri.

\section{B ÖL ÜM \\ SINNDİIM SİSTEMINNDEKİ KÖK HÜCRELER}

Diş Kökenli Kök Hücreler............................................. 514

Diş Pulpası Kök Hücreleri (DPKH ve SDKH) ..... 515

Periyodontal Ligament Kök Hücreleri (PDLKH) .. 518 
Apikal Papilla Kök Hücreleri (APKH) .................. 518

Dental Folikül Öncü Hücreleri (DFÖH) ............... 519

Karaciğerin Kök Hücreleri ve Onarımı..................... 520

Karaciğerin Kök/Öncü Hücreleri (Oval Hücreler).. 521

Oval hücreler ve karaciğer kanseri ......................... 524

Karaciğer Dışındaki Hücrelerden Hepatosit

Geliştirilmesi ............................................................... 524

Karaciğerde Onarım.............................................. 526

Onarm sinyalleri ................................................. 526

Besleyici maddelerin ve hormonlarm etkisi............. 527

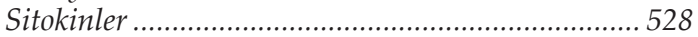

Pankreasın Kök Hücreleri............................................ 528

Pankreasın Gelişmesi, Hücresel Yapısı ve İşlevleri.. 528

$\beta$ Hücresinin Yenilenmesi ...................................... 531

$\beta$ Hücresinin Yenilenmesinde Diğer Kaynakların

Rolü ........................................................................ 532

Pankreas Kök Hücresinin Yerinin Belirlenmesi ... 533

Diabetes Mellitusun Hücre ile Tedavisi..................... 535

EKH'nin İnsülin Üreten Hücreye Dönüştürülmesi ...... 535

uPK Hücrelerinin İnsülin Üreten Hücreye

Dönüştürülmesi 536

$\beta$ hücresi Dışındaki Hücrelerin $\beta$ Hücresine

Dönüştürülmesi

536

Diabetes Mellitusta Kök Hücre

Tedavisinin Geleceği

Midenin Salgı Epiteli Kök Hücreleri .538

Mide Epitelinin Yapısı ve

Mide Epitelindeki Kök Hücreler 538

\section{BÖLÜM \\ EPITEL DOKULARINDAKİ KÖK HÜCRELER}

Epidermis ve Keratinosit Kök Hücreleri..................... 548

Epidermis ve Dermisin Gelişmesi......................... 549

Keratinositler ve Epidermisin Katmanları............ 550

Sitokeratin proteinleri .......................................... 552

Keratinosit Kök Hücrelerinden Epidermisin

Oluşması

Farklı Çoğalma Yetkinliğine Sahip Keratinosit

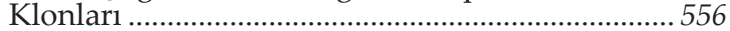

Epidermis Çoğalma Birimi ..................................... 558

Keratinosit Kök Hücrelerinde Klon Dönüşümü.. 558

Keratinosit Kök Hücresi Temelli Tedaviler .......... 559

Yaygın Yanıklarda KerKH Nakli............................ 561

Nakil Sonrasında Epidermisin Yenilenmesi......... 562

KerKH'nin Klinikte Kullanımı ................................ 563

Gelecekteki Gelişmeler ve Ekonomik Boyut........ 564
Sonuç ...................................................................... 564

Meme Bezi ve Kök Hücreleri...................................... 565

Meme Bezinin Gelişimi ve Yapısı............................ 565

Meme Bezindeki Kök Hücreler .............................. 567

Akciğerlerdeki Kök Hücreler ..................................... 568

\section{B ÖL ÜM \\ TESTİS VE OVARYUMDAKI KÖK HÜCRELER}

Testisin Yapısı ve Spermatogonyal Kök Hücreler ... 577

S.permatogonyal Kök Hücrelerin Ortaya Çıkışı ve

Özellikler

Spermatogonyal Kök Hücre Nişi.............................. 581

Erkekte Germ Hücreleri Nişi Üzerine Etkili

Hormonlar 581

Spermatogonyal Kök Hücrelerin Üreme

Sürecindeki Dinamikleri

Ovaryumun Yapısı ve Ovaryumdaki Kök Hücreler... 587

Embriyoda Gametogenez ve Ovaryum Kök Hücre

Nişi

Yetişkinin Ovaryumunda Yeni Folikül Oluşumu.... 592

Kök ve Öncü Hücrelerden Yapay Gamet Üretimi... 594

Kanser Kök Hücrelerinin Kökeni ve Oluşumu........ 604

Varsayım 1: Kanser kök hücreleri normal

kök hücrelerden kaynaklanır.................................. 606

Varsayım 2: Kanser kök hücreleri

öncü hücrelerden kaynaklanır ................................. 606

Varsayım 3: Kanser kök hücreleri farklılaşmış

hücrelerden kaynaklanır. .606

Kanser Kök Hücresi Belirteçleri ve

Hücre Dinamikleri 606

Kanser Kök Hücrelerindeki Sinyal Yolakları ........... 608

Wnt/ $\beta$-catenin Sinyal Yolağ 1 .................................... 608

Sonic Hedgehog (Shh) Sinyal Yolağı ..................... 612

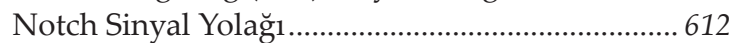

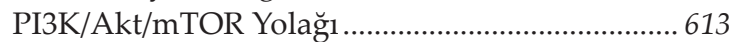

Sitokinler, STAT ve NFאB Yolakları ....................... 614

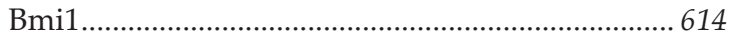


Kanser Kök Hücre Nişi ve Metastaz 614

Kanser Kök Hücrelerini Hedef Alan

TedaviYaklaşımları

DNA Hasarı Yanitı

DNA'nin onarim ve kanser.

615

616

.618

ABC Taşıyıcıları ve Çoklu İlaç Direnci.

Wnt/ $\beta$-catenin Sinyal Yolağının Baskılanması ..... 620

Non-steroid anti-inflamatuvar (NSAI) ilaçlar.........6 620

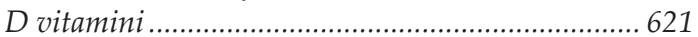

Antikor temelli tedavi yaklaşımları ........................ 621

Küçük moleküllü inhibitörler ................................. 621

Kanser İlaçlarına Direnç ve ABC Taşıyıcılarının

Engellenmesi.

Işın Tedavisine (Radyasyon) Direnç.

623

Epitel Mezenkim Geçişinin (EMG) Durdurulması . 623

Aldehit Dehidrogenaz Etkinliğinin Baskılanması 624

MikroRNA'nın Hedeflenmesi

624

Sonuç

624

\section{EKLER}

Ek 1 - Kök Hücre Belirteçleri .................................... 635

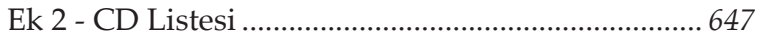

Ek 3 - Sitokinler ............................................................. 673

Ek 4 - İnsan Vücudunda Bulunan Hücre Tipleri..... 679

Ek 5 - Kök Hücre Alanındaki Tarihsel Gelişmeler .. 687

\section{Dìîn}

Dizin 701 



\section{ÖNSÖZ}

\section{(Birinci Bask1)}

Bir yandan embriyoloji ve hücre biyolojisindeki ilerlemeler, diğer yandan hastalıkların kişiye özel yöntemlerle tedavi edilmeye yönelik girişimlerin artması, organizmanın gelişmesi ve yaşamını sürdürmesini sağlayan kök hücreleri, yaşam bilimleri alanında en çok çalışılan konulardan birisi hâline getirdi. Kuşkusuz, bu alanın öncüleri, bundan yaklaşık 35 yıl önce, ilk tüp bebek uygulamasıyla dünyaya getirilen ve bugün sayıları milyonlara ulaşan bireylerin, yaşamını sağlıklı biçimde sürdürüyor olmasını sağlayan bilgi birikimini ve teknolojiyi kullandı. Besi hayvanları ve nesli koruma altına alınmaya çalışılan hayvan türleri için çekirdek nakli ve tedavi amacıyla uygulanan klonlama teknolojileri de kök hücre çalışmalarına önemli destek sağladı, öyle ki geldiğimiz noktada, bu alanları birbirinden kesin çizgilerle ayırmak artık söz konusu değil.

Çok değil, bundan 20 yıl öncesine kadar yetişkin organizmada sadece bir tür kök hücre bulunduğu varsay1lıyordu - hematopoetik kök hücre. Şimdilerde ise embriyo döneminde gördüğümüz birçok kök ve öncü hücrenin yetişkin organizmadaki karşılıklarını, kalıntılarını bulmaya çalışıyoruz, bir bölümünü de buluyoruz doğrusu. Ancak çoğu kez, "kök hücre" teriminin gereksiz yerde ve doğru kullanılmadığını da izliyoruz. "Kök hücre", kuşkusuz tek bir hücreyi tanımlamıyor; farklı düzeylerde farklılaşma ve çoğalma yetenekleri kazanmış, birbirinden çok farklı yapı ve gelişim süreçlerindeki hücreleri bu kapsam altına alıyoruz. Bu nedenle, kök hücre kavramını da, hücre ve hatta bulunduğu doku veya gelişim süreci özelinde değerlendirmemiz gerekiyor.

Kök hücreler üzerine yapılan çalışmaların bu denli artması, birçok ülkede, hücre üretme, işleme ve saklama şirketlerinin sayısının son yıllarda âdeta patlaması, deneyimli akademisyenlerin bu şirketlere kayması, bu hücrelerin önümüzdeki dönemde tıp alanında "kök hücre temelli tedaviler" adıyla yeni bir akımın başlayabileceğini göstermekte. Özellikle yaşam süresinin uzamasıyla ortaya çıkan dejeneratif hastalıklar, milyonları ilgilendiren doku ve organ yaralanmaları veya kayıpları, kanserin oluşumunda kök hücrelerin rollerinin belirlenmeye başlaması, bu alandaki çalışmaların bir süre daha büyük bir hızla süreceği izlenimini vermekte.

Tüm gelişmiş ve gelişmekte olan ülkelerde olduğu gibi, ülkemizde de özellikle tıp, veterinerlik ve biyoloji alanlarında çalışan araştırmacıların bir bölümünün ilgisinin son yıllarda kök hücre alanına doğru kaydığını gözlemekteyiz. Ardı ardına yapılan sempozyumlar, uzmanlık alanlarına yönelik kongrelerde kök hücre oturumlarının düzenlenmesi, uygulamaya yönelik kurslar, araştırma desteği sunan kurumlara kök hücreyle ilgili başvuruların sayısındaki belirgin artış, bunun en tipik göstergesi olarak kabul edilebilir. Yanı sıra, üniversitelerde bu konuya ilişkin özel araştırma ve tedavi birimlerinin açılması; enstitü ve merkezlerin kuruluyor olması, bu alana olan ilginin giderek arttı̆ının en somut delili olmakta. Kök hücre kullanılarak yapılacak olan girişimlerin önünde bekleyen tıbbi, teknolojik ve etik sorunlarla yeni yeni yüzleşen bilim insanlarının, abartısız ve gereğinden fazla umut vermeden söz konusu alanda öncü çalışmalara imza atmak için birbiriyle yarıştığını, öte yandan söz konusu hücreleri elde etmek, işlemek, depolamak ve gerektiğinde kullanılacak merkeze nakletmek için "anahtar teslimi" hizmet vermeye hazırlanan özel kuruluşların ruhsat alma ve pazar payını artırma çabası içine girdiğini görüyoruz. 
Tüm bunlar olagelirken, özellikle konuyla yeni ilgilenmeye başlayanlar için, dilimizde kaleme alınmış, kaynak niteliğinde bilgi bulmanın güçlüğü de fark edilmeye başladı. Kurs notları, kongre bildirileri ve TÜBA gibi kurumların konuyu kısıtlı ele alan yayınları dışında günümüzde, kök hücre alanının tümünü ele alan bir kaynak kitap eksikliğinden yola çıarak elinizdeki kitap hazırlandı. Bu kitaba konu olan, sadece organizmanın tek bir hücresi değil, yaşamın başlangıcında ortaya çıkıp tüm yaşam boyunca işlev görev bir dizi hücrenin temel biyolojik özellikleri, vücuttaki dağılımları ve günümüzdeki tedavi amacıyla kullanımları olduğu için, belki de ilk kez, bu denli farklı disiplinden gelen kişilerin ortak ilgi noktası olmayı başardı.

Bilim dili, bugün, bilindiği üzere, büyük oranda İngilizcenin etkisi altına girmiş durumda. Öyle ki, birçok protein ve benzeri biyomolekülün ismi İngilizce'den türetilmeye başlandı. Örneğin, CREM proteini, yani açıkça yazmak gerekirse $c A M P$-responsive element modulator ve her gün bunun gibi onlarcası karşımıza çıkmakta. Bu durumda, İngilizceden başka bir dilde kitap, rapor, tez, makale kaleme almak; gerektiğinde bu terimleri Türkçede okunduğu gibi yazmak yerine, taşıdığı anlamı yitirmeden Türkçeye çevirmek; bunun yanı sıra, yabancı literatürü izlemek isteyenler için de yaygın kullanılan İngilizcedeki karşılığını da ek olarak vermek gerekmektedir. Bu kitapta da bu yol izlenmiştir; birçok terim ve tanımlama, olabildiğince Türkçeleştirilmiştir; yabancı dildeki isim ve sıfat kökleri yerine (örneğin; "embriyonik" demek yerine "embriyo"; "intestinal" demek yerine "bağırsak" demek vb.) Türkçe isim ve sıfat tamlamaları kullanılmış, ancak parantez içinde ve italik olarak yabancı dildeki karşılıkları da verilmiştir. Çok yaygın kullanılan yabancı terimlerse değiştirilmemiştir (örneğin; pluripotent). Genel yazım kuralı gereği, gen isimleri italik olarak, kodladıkları proteinler dik yazıyla yazılmışlar; protein kaynağı hayvansa küçük harfle, insansa büyük harfle yazılmıştır. Ancak birçok protein için bu ayrımı yapmak mümkün olamadığından küçük harf kullanımı tercih edilmiştir. Bazı proteinlerin kısaltılmasının ise kökeninden bağımsız olarak büyük harfle yazıldığını göreceksiniz (GATA, STAT vb.). Proteinlerin birçoğu orijinal isimleriyle bırakılmış (örneğin; cadherin), ancak yıllardır çok yaygın kullanılanları ise ya Türkçeye çevrilmiş (örneğin; hücrelerarası yapışma molekülü) ya da okunduğu gibi yazılmıştır (örneğin; reseptör tirozin kinaz) Türkçedeki yazım kuralları için www.tdk.gov.tr adresi kullanılmıştır.

Zaman içinde bu kitapta sunulan bilgilerin ve araştırma sonuçlarının eskiyeceği, belki de bazılarının geçerliliğini yitireceği bilinse de, temel kavramların on yıllar boyunca değişmeyeceğini öne sürmek mümkün gözükmektedir. Yukarıda özetlendiği gibi, en hızlı gelişen araştırma alanlarından birisi olmasına karşın, kök hücrelerin kökenini, davranış biçimlerini ve hatta organizmadaki dağılımlarına ilişkin bilgilerimizi anlaşılabilir bir sistem içinde okuyucuya sunmak oldukça karmaşık bir dizi bilgiyi bir araya getirmeyi gerektiriyor. Birçok tanımın üst üste çakıştığını, gelişim biyolojisi açısından uzun yıllardır bilinen bazı kavramların şimdilerde başka terimlerle anıldığını, bazı tanımlamalarda ve ölçütlerde fikir birliğine varılamadığını fark edebilirsiniz. Bu da bu kitabın belli aralıklarla yenilenmesi gerektiğinin sinyallerini şimdiden ortaya koyuyor.

Yararlı olması ümidiyle.

Prof.Dr. Alp Can

Ankara - 2013 


\section{ÖNSÖZ (İkinci Baskı)}

Birinci baskısı 2014 yılında okuyucuyla buluşan KÖK HÜCRE. Biyolojisi, Türleri ve Klinik Kullanımları geçtiğimiz yedi yıl içinde sizlerden çok büyük ilgi gördü. Satış grafiklerini izlemesem de bana ulaşan geri bildirimlerin zaman içindeki seyri yayınlandıktan özellikle bir iki yıl sonra çok yaygın okunmaya başladığını gösterdi. O kadar çok beğeni aldım ki, bunları buraya taşımam çok zor. Birçok üniversitede yüksek lisans ve doktora programlarının temel kitabı olduğunu mutluklukla öğrendim.

Öncelikle mezuniyet sonrası öğrencilerini ve uzmanları hedefleyerek yazmış olduğum bu kitap, özelllikle tıp fakültesi eğitimlerinde giderek popülerleşen ve adından çok söz ettiren kök hücrelerden sonra öğrencilerimizin de ilgisini çekmeye başladı. Son yıllarda kök hücre konusunda çok sayıda öğrenci topluluğu kuruldu. Bunların yapmış olduğu sempozyumlarda imzaladığım kitapların öğrenciler tarafından da büyük ilgiyle okunduğunu görmek beni çok memnun etti. Buradan yola çıkarak kitabın yanı sıra daha güncel br kaynak olabilmesi amacıyla 2014 yılından başlayarak Kök Hücre E-Bülteni'ni (KHB) yayınlamaya başladık. Kitap temel ve kapsamlı bilgileri akademik düzeyde sunarken KHB günceli daha samimi bir dille kısaca sunma görevini üstlendi. 2021 itibariyle 40. sayısına ulaşan KHB'nin izleyicisi de 2500'ü aşmış durumda.

Benim cephemden bakıldığında kök hücre alanındaki yazı faaliyetleri hiç kesilmeden sürmek zorunda. Ancak diğer akademik faaliyetler ve her geçen gün artan iş yükümüz zaman zaman bu yazım görevlerimizi tehdit etme noktasına geliyor. Öye yandan, kitaba olan yoğun talep, 2020 itibariyle ilk baskısının (3000 adet) tükenmesine neden oldu. Akademisyen Kitabevi ve diğer dağıtıcılar stoklarındaki kitapları sonuna kadar tükettileri bilgisini bana ilettiler. Lisans öğrencilerimizin ve bu alana katılan yeni yüksek lisans, doktora ve tıpta uzmanlık öğrencilerinin artan talepleri üzerine kitabı yeniden basma kararı aldım. Bunu yaparken diş görünümünü yenilemenin yanı sıra gözüme çarpan yazım hatalarını düzelttim ve Ek-5'teki gelişmeleri güncelledim. Kitabın bu haliyle bir süre daha bu alandaki bilgi boşluğunu karşılayabileceğini düşünüyorum. Bundan sonraki aşama, kitabın güncel bilgilerle yeniden ele alınarak 3. baskısını yazmak olacaktır.

O günleri de görmek ümidiyle.

Prof.Dr. Alp Can

Ankara - 2021 


\section{TEŞEKKÜR}

Her ne kadar, bu kitabın kapağında sadece bir tek isim yer alsa da, böylesi bir projeyi gerçekleştirmek için gerekli laboratuvar deneyimi ve bilgi birikiminin ortaya çıkmasına yardımcı olan, birlikte çalıştığım çok sayıdaki bilim insanına burada teşekkür etme ayrıcalığına sahibim.

İrili ufaklı olsa da, bu kitap benim kaleme aldığım yedinci kitap olarak sırada yerini alıyor. Her zaman olduğu gibi özel yaşantımdan çaldığım zamanları bu kitabı yazmak için kullandığım için sevgili eşim Prof. Dr. Ufuk Can'a ve biricik kızım Selin ve oğlum Barış'a teşekkür ederim. Yazım süresini görece kısa tutarak (yaklaşık 1,5 yıl) onlarla paylaştığım saatleri uzatmaya çalıştığımı düşünsünler isterim. Kendileri muhtemelen bu teşekkür sayfalarını okumaktan çoktan vazgeçmiş olsalar da onların desteğini arkamda hissetmek bana güç verdi. Eşimin neredeyse bütün kitabı okuyarak yaptığı bilimsel katkıya ayrıca teşekkür ederim.

1990'ların başından itibaren bugünkü hâline gelene kadar sorumlusu olduğum üreme biyolojisi ve kök hücre laboratuvarlarında birlikte çalıştığım tüm öğrencilerimin isimleri bu sayfada yer almak zorundalar. 1990'lı yılların ortalarından başlamak gerekirse sevgili Dr. Ayça Işık ve Doç. Dr. Olcay Semiz'e; 2003 yılında kök hücre konusundaki çalışmalara başladığımız sevgili Doç. Dr. Özgür Çınar, Dr. Serçin Karahüseyinoğlu ve Dr. Sinan Özkavukcu'ya ve son uzmanlık öğrencim olan sevgili Dr. Zeynep Gülhan'a; Biyoteknoloji Enstitüsü öğrencilerim sevgili Deniz Balcı, Ayşe Yüzbaşığlu, Duru Aras ve Hakan Coşkun'a; Sağlık Bilimleri Enstitüsü öğrencilerim olan sevgili Pınar Akpınar Oktar, Aynur Karadağ ve Rıza Dastouri'ye; bir ara bizlerle birlikte çalışan sevgili Banu Boz, Gonca Koçancı, Esra Oktay'a; yıllardır bizleri hiçbir zaman dokusuz bırakmayan sevgili Doç. Dr. Fadıl Kara'ya teşekkür ederim. Kendi konularındaki bölümleri gözden geçirerek değerli katkılar yapan Prof. Dr. Sibel Yıldırım'a, Doç. Dr. Hilal Özdă̆’a, Prof. Dr. Ali Uğur Ural'a, Doç. Dr. Utku Ateş'e; benimle yıllardır aynı koridoru paylaşan Ankara Üniversitesi Tıp Fakültesi Histoloji ve Embriyoloji Anabilim Dalı öğretim üyelerine, uzmanlarına, asistanlarına ve teknisyenlerine teşekkür ederim.

Yıllardır süren kesintisiz çalışmalarımız, kuşkusuz çok sayıdaki kurumun desteğiyle gerçekleşti. Bu bağlamda, Ankara Üniversitesi, BAP, TÜBITAK-SBAG, Devlet Planlama Teşkilatı, Sanayi ve Teknoloji Bakanlığı yöneticisi ve çalışanlarına teşekkür ederim. Yanı sıra yayınıım Sn. Yasin Dilmen ve kitabın elinizdeki biçimini almasına yardımcı olan Sn. Dilek Meraki'ye teşekkür ederim.

Son ve büyük teşekkürlerim de çok sevgili annem ve babama. Kök hücrelerimi onlardan aldım... 